\title{
II. 治療の進歩
}

\section{1. 下垂体疾患治療の進歩}

\section{高野 幸路}

要旨

下垂体疾患の臨床は近年大きく進歩した，外科治療の進歩に加え，有効な内科治療薬が多くの分野で複 数開発された。これにより, 先端巨大症, プロラクチノーマなどでは大多数の患者を治癒状態にできるよ うになってきている，これには，各疾患の病態生理が明らかになり，治療薬の作用機構も詳細に解明され たことも大きく寄与している. 基礎研究, 臨床研究の成果により優れた治療薬の開発がなされてきた. 本 稿ではその一端を紹介したい.

〔日内会誌 $101 ： 975 \sim 984 ， 2012 〕$

はじめに

下垂体疾患の治療は近年大きく進歩した。中 でも，薬物治療は作用機構や特徽の異なる治療 薬が開発されている. 本稿では先端巨大症，プ ロラクチン産生腫瘍, 下垂体癌の治療薬と, 成 人 GH分泌不全症に対する $\mathrm{GH}$ 補充療法について紹 介する。

\section{1. 先端巨大症の治療薬}

\section{1）先端巨大症の治療目的}

先端巨大症は, 未治療の場合生命予後が悪化 し, またQOL (quality of life)の低下, 合併症の 発症によって患者を長期にわたり苦しめる疾患
である.生命予後の悪化については, コントロー ル不良の場合に死亡率の $2 \sim 3$ 倍の上昇が認めら れることが多くの臨床研究に報告されており ${ }^{1)}$, 本邦の厚生労働省間脳下垂体機能障害調査研究 班の調査結果でもこのことは明らかになってい

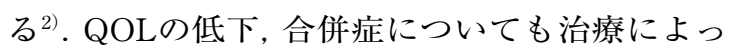
て改善することが多くの臨床研究で報告されて いる. 先端巨大症の治療により, 治癒基準が達 成されると, 生命予後が一般人口と同程度にな り, QOLの改善, 合併症の改善が報告されてい る $(\text { 図 1 })^{3)}$.これらのことから, 先端巨大症の治 療は治癒を目指して, 外科治療, 内科治療, ま た選ばれた症例において定位放射線治療を組み 合わせて集学的に行われている.

生命予後を正常化し, 合併症, QOLの改善を 達成するために，治癒基準を達成することが重

東京大学腎臟 · 内分泌内科

Endocrine Disease:Progress in Diagnosis and Treatment. Topics:IL. Progress in Treatment;1. Development of medical treatment for pituitary disease.

Koji Takano : Department of Nephrology and Endocrinology, Faculty of Medicine, the University of Tokyo, Japan. 


\section{トピックス}

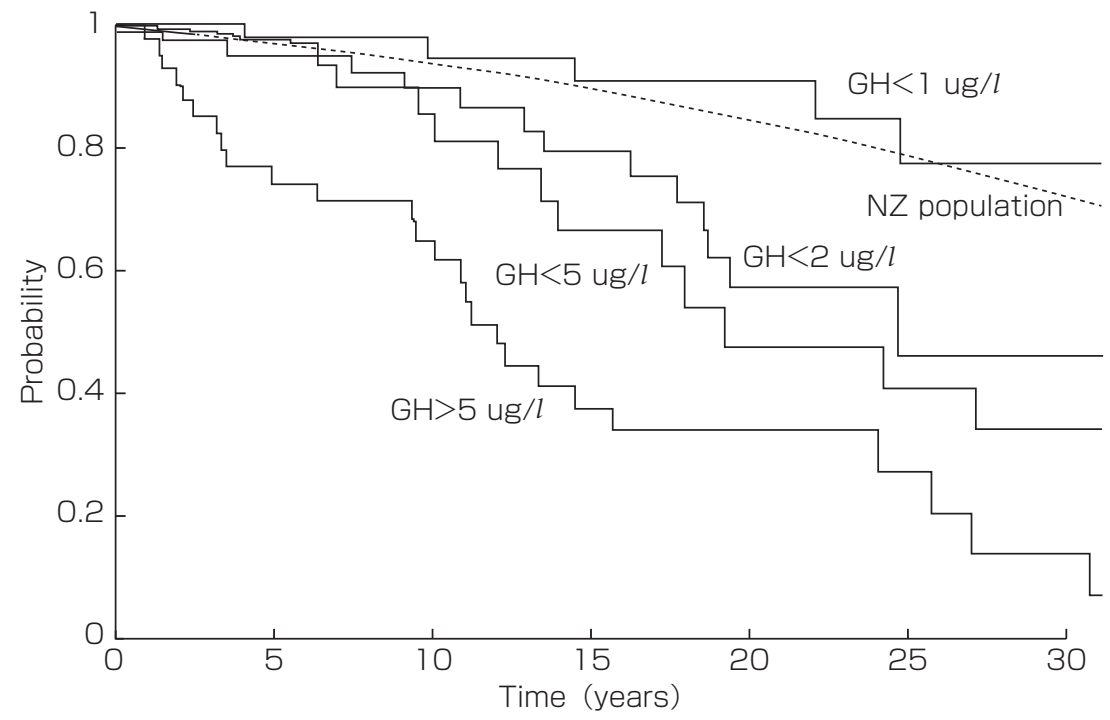

図 1. 先端巨大症患者の生命予後

先端巨大症患者の最終外来GH值と生命予後の関係をNew Zealandの一般人口の 生命予後（NZ population）と比較したKaplan-Meyer法による解析 (文献 3 より引用)

表 1. 先端巨大症の治療効果判定基準 (参考文献 5 より改変)

\begin{tabular}{|c|c|c|}
\hline & 基準 & 管理方法 \\
\hline 活動性あり & $\begin{array}{l}\text { Random GH値> } 1 \mathrm{ng} / \mathrm{ml} \text { かつ } \\
\text { OGTTでのGH底值 } \geqq 0.4 \mathrm{ng} / \mathrm{ml} \\
\text { 性別年齢別のIGF-1 の基準值以上 } \\
\text { 臨床的活動性あり }\end{array}$ & $\begin{array}{l}\text { 定期的にMRI撮影 } \\
\text { 活動性の評価と合併症の治療 } \\
\text { 積極的に治療や治療法の変更を考える }\end{array}$ \\
\hline 管理されている & $\begin{array}{l}\text { Random GH値 }<1 \mathrm{ng} / \mathrm{ml} \text { または } \\
\text { OGTTでのGH底值 }<0.4 \mathrm{ng} / \mathrm{ml} \\
\text { 性別年齢別のIGF-1 の基準值以内 } \\
\text { 臨床的活動性なし }\end{array}$ & $\begin{array}{l}\text { 定期的にMRI撮影（2-3 年に一回など） } \\
\text { 治療を継続する } \\
\text { ソマトスタチン治療の場合は減量を考慮 }\end{array}$ \\
\hline \multicolumn{3}{|c|}{$\begin{array}{l}\text { 外科治療後はOGTTとIGF-1 で評価 } \\
\text { ソマトスタチンアナログ治療の場合はrandom GHで管理, 採血結果が臨床所見と合わない場合は } 2 \text { 時 } \\
\text { 間の間に } 3-5 \text { 回採血したGHの值で評価 }\end{array}$} \\
\hline
\end{tabular}

要であることが明らかになっている．治瘉基準 は時代とともに厳しくなっている. 2000 年に発 表されたCortina consensusの治癒基準では不十 分であるとして 2010 年に治癒基準の改定が示さ れた．図 1 に示すように, 薬物治療では外来の $\mathrm{GH}$ 值が $1 \mathrm{ng} / \mathrm{ml}$ 未満を達成する, 術後の場合は 糖負荷後に $0.4 \mathrm{ng} / \mathrm{ml}$ 未満を満たすものを治癒と する $(\text { 表 } 1 \text {, 図 2) })^{5}$. 本邦においては厚生労働省
間脳下垂体機能障害調査研究班から治癒基準が 提唱されており $(\text { 表 } 2)^{6}$, 治癒, コントロール不 十分, コントロール不良の 3 つの群に分けて考 えている. 治癒を目指して治療を行うのが基本 である。

\section{2）治療方法の種類と内科治療}

先端巨大症の治療の第一選択は外科治療であ る.外科治療が可能ならば, 習熟した術者によっ 


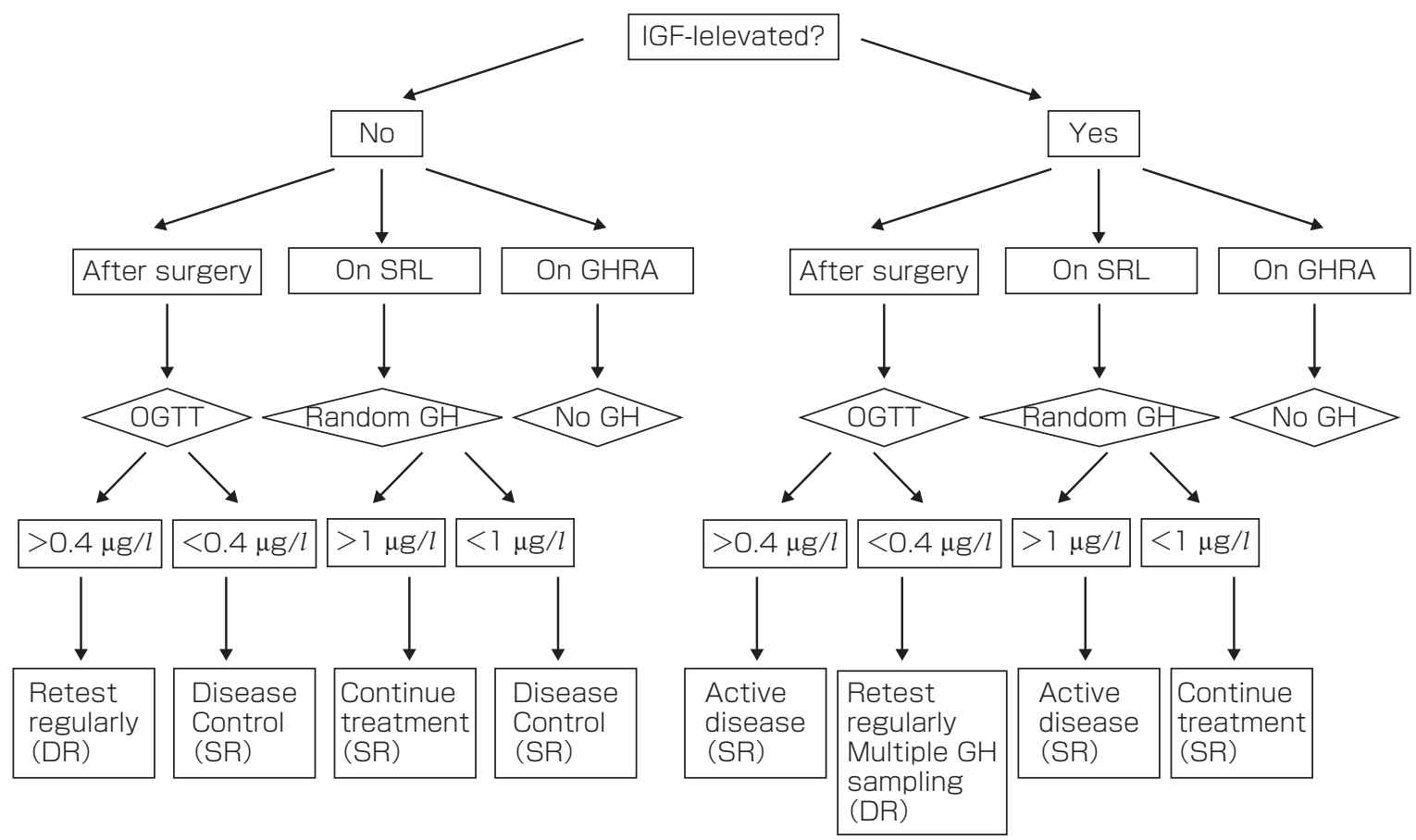

図 2. 先端巨大症患者の治療と経過観察のアルゴリズム（文献 5 より引用）

表 2

平成 17 年度 厚生労働省間脳下垂体機能障害調查研究班報告書より引用

\begin{tabular}{|c|c|}
\hline $\begin{array}{l}\text { コントロール良好 } \\
\text { (治癒または寬解) }\end{array}$ & $\begin{array}{l}\text { ブドウ糖経口負荷後のGH底值が } 1 \mathrm{ng} / \mathrm{ml} \text { 未満，かつIGF-I 值が年齢・性 } \\
\text { 別基準值内であ床的活動性を示す症候が全くない }\end{array}$ \\
\hline コントロール不十分 & 1 および 3 のいずれにも該当しないもの \\
\hline コントロール不良 & $\begin{array}{l}\text { ブドウ糖経口負荷後のGH底值が } 2.5 \mathrm{ng} / \mathrm{ml} \text { 以上, かつIGF- I 值が年齢 } \\
\text { 性別基準值を超える臨床的活動性を示す症候がある }\end{array}$ \\
\hline
\end{tabular}

て腫瘍切除術を受けることが, 医療経済的にも， 患者の負担においても薦められる。外科治療の 進歩により, $1 \mathrm{~cm}$ 未満のmicroadenomaでは慣れ た施設では 9 割を超える治癒率が期待できる. macroadenomaについては施設間の相違はあるも のの 50 ～85\% の治癒が期待できるようになって いる.

心不全などで外科治療がはじめから困難な例 や，外科治療後に治癒に至らなかった場合は内 科治療が適応になる。

内科治療に用いられる薬剤の開発はこの 20
年間に大きく進み, 治療薬の種類, 有効性, 治 療の受け入れやすさの改善において著しい進歩 があった。これらから, 手術療法で治癒が得ら れない場合は内科治療を優先することが推奨さ れている.

一方放射線治療については, かつては内科治 療の発達が不十分であったこともあり，外科治 療の次の治療手段であった。しかし，外照射治 療をうけた患者の生命予後が改善しないことか ら，現在では限られた症例でしか適応にならな い. 外照射治療を受けた患者において生命予後 


\section{トピックス}

表 3. 先端巨大症患者の原因別死亡率（文献 7 より引用）

\begin{tabular}{|c|c|c|c|c|}
\hline Cause & Observed deaths & Expected deaths & SMR (95\% CL) & $P$ \\
\hline All-cause & 95 & 75.5 & $1.26(1.03-1.54)$ & 0.045 \\
\hline Cerebrovascular & 20 & 7.5 & $2.68(1.73-4.15)$ & 0.007 \\
\hline Cardiovascular & 35 & 25.6 & $1.37(0.98-1.90)$ & 0.111 \\
\hline Respiratory & 13 & 8.6 & $1.52(0.88-2.61)$ & 0.219 \\
\hline Malignancy & 21 & 23.1 & $0.91(0.59-1.39)$ & 0.650 \\
\hline \multicolumn{5}{|c|}{ 放射線治療を受けた患者の原因別死亡率 } \\
\hline Cause & Observed deaths & Expected deaths & SMR (95\% CL) & $P$ \\
\hline All-cause & 59 & 37.4 & $1.58(1.22-2.04)$ & 0.005 \\
\hline Cerebrovascular & 16 & 3.6 & $4.42(2.71-7.22)$ & 0.005 \\
\hline Cardiovascular & 20 & 12.5 & $1.60(1.03-2.48)$ & 0.096 \\
\hline Respiratory & 7 & 4.0 & $1.75(0.84-3.68)$ & 0.261 \\
\hline Malignancy & 12 & 12.0 & $1.00(0.57-1.76)$ & 1.000 \\
\hline
\end{tabular}

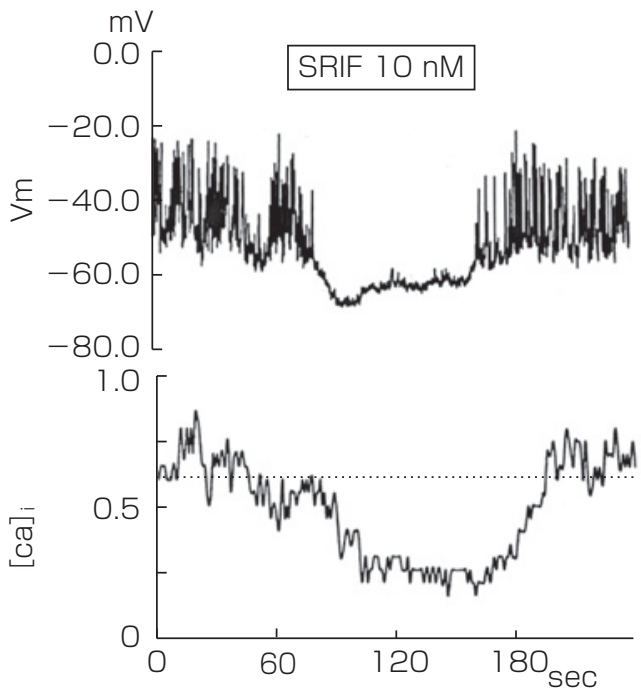

図 3. ソマトスタチンによるGH産生腺腫の過分 極反応, 活動電位の抑制と細胞内カルシウム濃度 の低下 (膜電位と細胞内カルシウム濃度の同時記 録）(文献 8 より引用)

が改善しない原因として, 外照射治療を受けた 患者群で脳血管合併症による死亡率の増加が見 られる（odds比約 4 倍）ことから，外照射によ る脳血管障害の発生が考えられている7 ${ }^{7}$.

\section{2. 内科治療法の種類と選択}

1) ソマトスタチンアナログ

ソマトスタチンアナログは, 現在内科治療の 第一選択となっている. 月 1 回の筋注製凨の開 発により，治療の受け入れやすさは格段に改善 した.ソマトスタチンアナログは約 6〜 7 割の患 者で治癒を達成する．また，半数以上の症例で 腫瘍縮小が認められ, 速い場合では 1 3 カ月で 効果が見られる。ソマトスタチンアナログによ るGH分泌抑制作用は次のようなものであること が明らかになっている。ソマトスタチンは $\mathrm{Gi}_{3}$ 蛋白を介した内向き整流性カリウムチャネルの 活性化により膜を過分極し，活動電位の発生を 抑え, 活動電位発生の際に細胞内に流入するカ ルシウム量が減少し, 膜直下のカルシウム濃度 の低下により GH分泌顆粒の顆粒分泌が抑制され る(図 3，4) 8.9)，ソマトスタチン受容体は多くの 腺腫に発現しており有効性は高い. 腫瘍縮小効 果は長期投与の場合, 腫瘍体積で平均 5 割減に 達する (図 5$)^{10)}$ 。また, 多くの受容体作動薬で は脱感作が生じることが知られているが，ソマ トスタチンアナログにおいてはほとんどの症例 


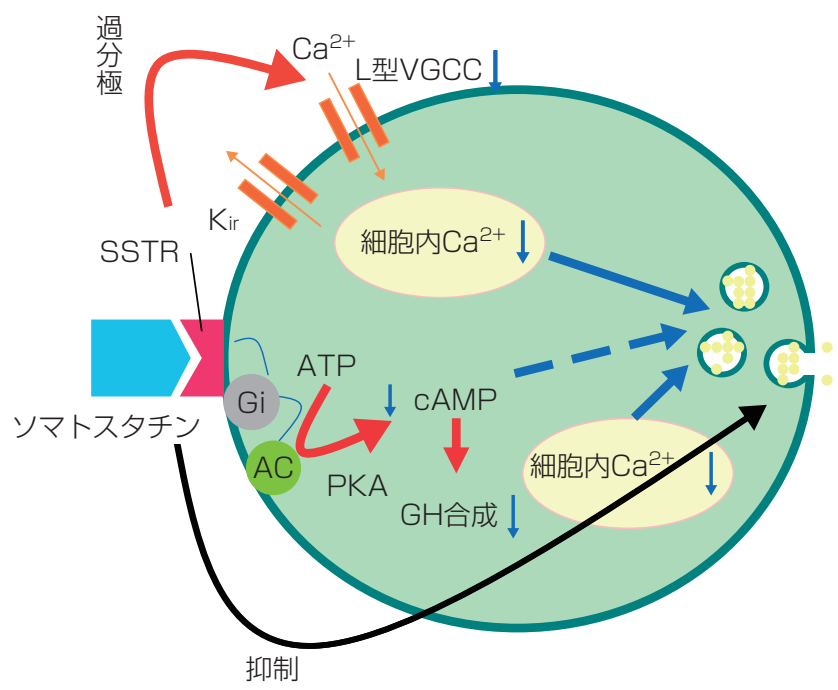

図 4. ソマトスタチンアナログの作用機構

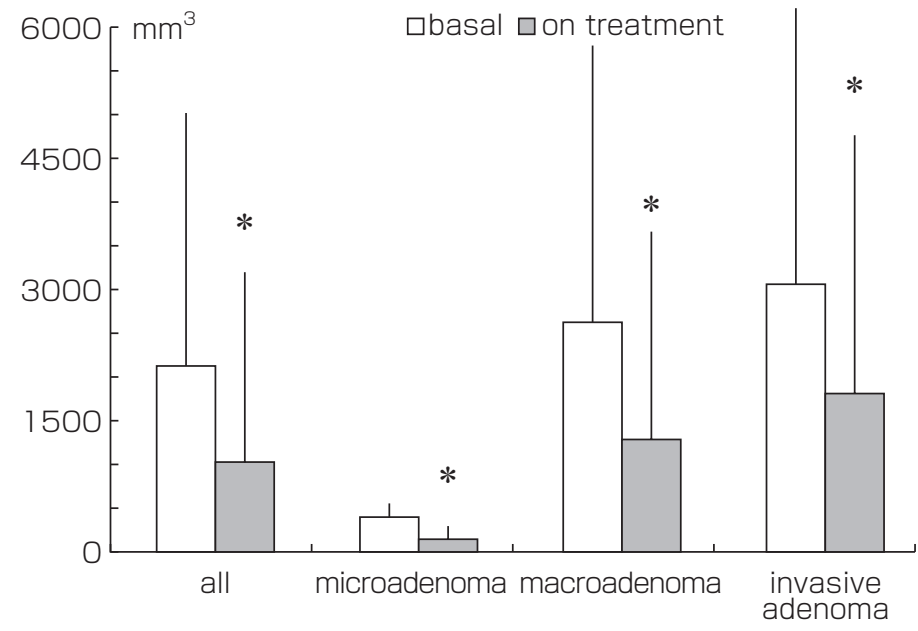

図 5. オクトレオチド治療による先端巨大症患者の腫瘍の縮小（文 献 11 より引用)

で長期間脱感作が起こらない (図 6 $)^{11)}$. GH分泌 抑制と腫瘍縮小の 2 つの作用が長期間認められ ることから, 手術のみで治瘉が得られないこと が予測されている大きい腫瘍の場合に，手術を 行わずにソマトスタチンアナログで内科治療を 行う primary therapyの是非が検討され, 治療方 法のひとつとしてガイドラインにも取り上げら れている ${ }^{12)}$. 一方, 手術によって腫瘍量を少なく
してから内科治療を行った場合に, primary therapyよりも治癒率を高くすることができるという ことも報告されており, 可能なら外科治療を第 一選択とし治癒に至らない場合に内科治療を加 えるというアルゴリズムの根拠になっている ${ }^{13)}$.

\section{2） $D_{2}$ 受容体作働薬}

一部の GH産生腺腫には $\mathrm{D}_{2}$ 受容体が発現してお り, $\mathrm{D}_{2}$ アゴニストが $\mathrm{GH}$ 分泌の抑制に有効である 


\section{トピックス}
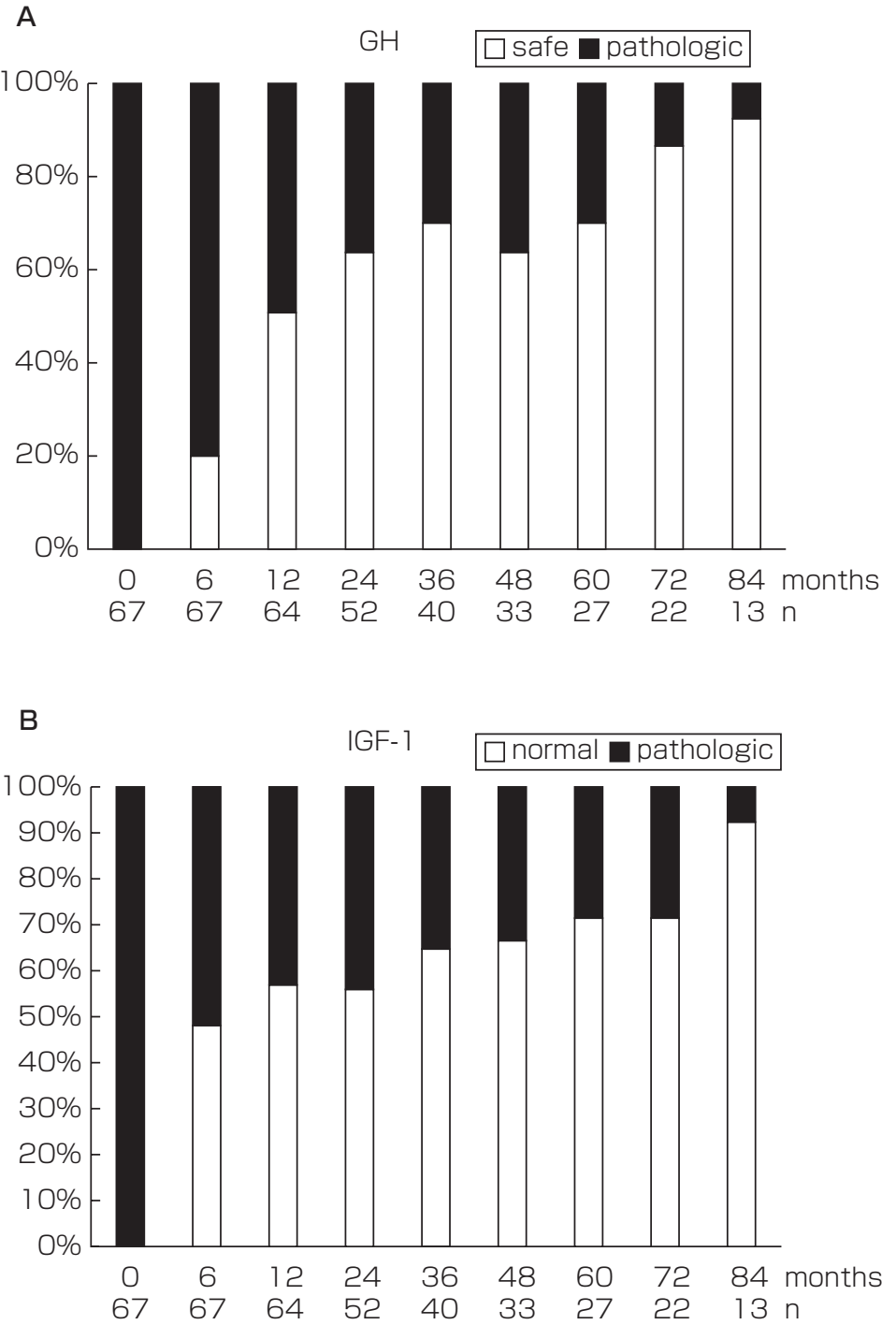

図 6

A. オクトレオチド長期使用による先端巨大症患者のGH值改善の経過 (文献 11 より引用)

B. オクトレオチド長期使用による先端巨大症患者のIGF 1 值改善の経 過（文献 11 より引用）

ことが報告されている， $\mathrm{D}_{2}$ アゴニストによって 膜の過分極反応が生じ, 細胞内カルシウム濃度 が低下し, GH分泌抑制が起こることが報告され ている ${ }^{14)}$. 本邦ではブロモクリプチンのみに適応 があるが，欧米ではカベルゴリンも用いられて いる. 最近のメ夕解析では, カベルゴリンで $34 \%$
に症例にIGF1 の正常化が達成できている15)。ま た，ソマトスタチンアナログで治癒にいたらな い症例で併用した場合 $52 \%$ にIGF1の正常化が達 成できている，いずれも，カベルゴリン治療前 のIGF1 值の高くないものほど正常化しやすいこ とがわかっている. 


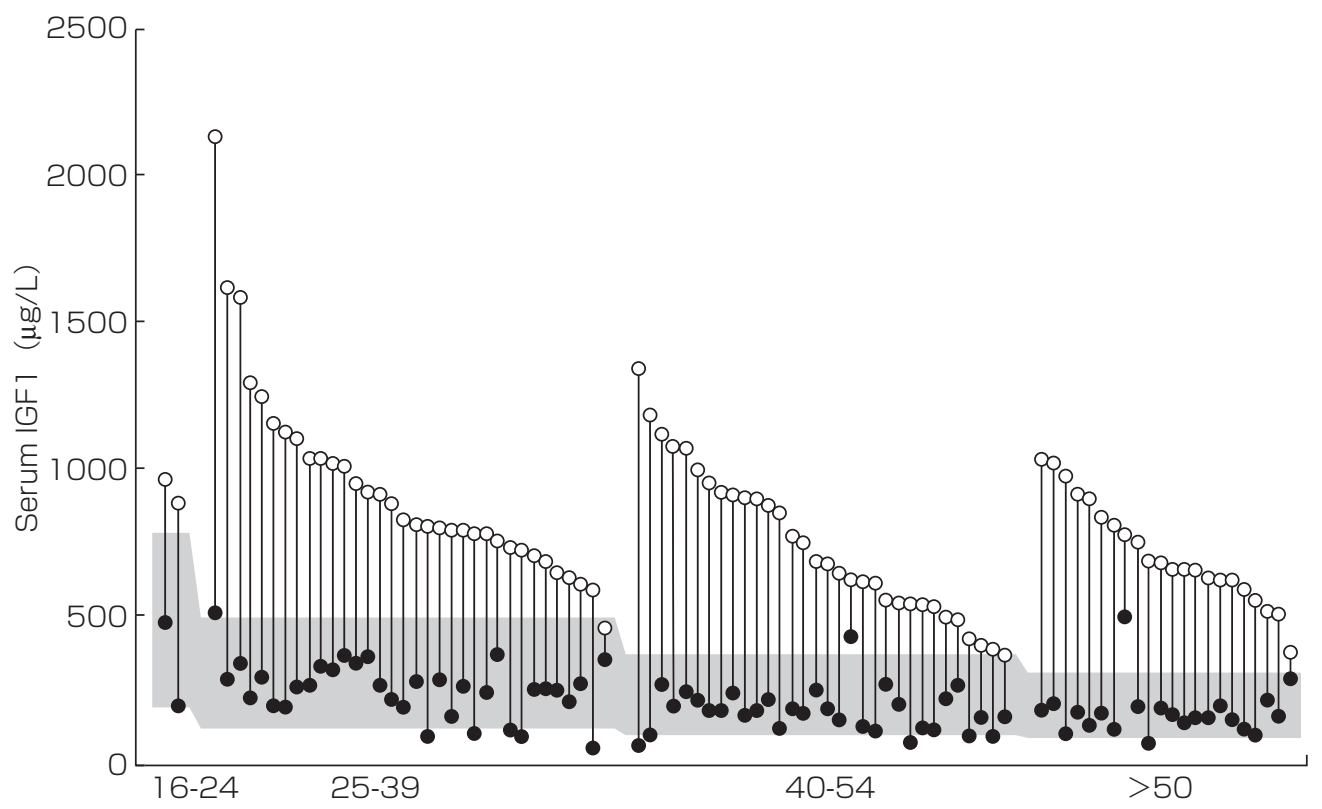

図 7. pegvisomant投与による先端巨大症患者のIGF 1 值の正常化（文献 15 より引用）

\section{3） $\mathrm{GH}$ 受容体拮抗薬}

$\mathrm{GH}$ 受容体拮抗薬のpegvisomantは, GH受容体 に強く結合するが, GHの刺激伝達経路を活性化 できないGHアナログとして開発された薬鼡であ る. GH作用を強く抑制し, 肝臓でのIGF1 産生抑 制にそれが反映されることから，治療の指標は IGF1 の正常化をもって行う (血中GH值は増加す る).一日一回の皮下注射により, 8〜9 割近くの 症例でIGF1 を正常化する ${ }^{16)}$. この薬剤は腫瘍に 作用するものではなく, GH分泌抑制効果や腫瘍 縮小効果はない。このため, 腫瘍容積が問題に なる症例では注意深く画像検査により腫瘍増殖 について経過観察を継続する必要がある．治癒 基準として, 年齢, 性別でのIGF1の正常化と臨 床的活動性の消失を用いる。 また, 治療初期に 一過性の肝酵素の上昇を $15 \%$ の症例でみとめる ので注意が必要である。しかし, 耐糖能異常の ある症例では, 耐糖能障害を軽減する利点があ ることが報告されている.

\section{3. ソマトスタチンアナログとGH受容体拮 抗薬combination therapyの位置づけ}

本邦ではGH受容体拮抗薬はソマトスタチンア ナログ不応性の症例の治療に適用されているが, 海外ではソマトスタチンアナログと週 2 回や毎 日のpegvisomantの併用療法が試みられてい る ${ }^{17)}$. 併用療法によってQOLの改善が得られた とする報告などがある. 今後の報告が期待され る.

\section{4. 今後の展望}

サンドスタチン以外のソマトスタチンアナロ グとして, ランレオチドやパシレオチドがある, ランレオチドの徐放製剤は現在本邦で治験を終 了している，海外では，すでに長期の成績が報 告されている製凨であり，サンドスタチンとほ ぼ同等の有効性が報告されている。サンドス夕 


\section{トピックス}

チンLARと異なり, 深部皮下注で投与され, prefilledの注射薬として提供される.

サンドスタチンはソマトスタチンのtype 2 と type5 の受容体に親和性が高い薬剤であるが, 1 , $2,3,5$ という多くの受容体夕イプに親和性の高 いpasireotideが, 先端巨大症に対して海外で治験 が終了している。 サンドスタチン不応性の腫瘍 に対する有効性も報告されている ${ }^{18)}$. また, 投与 方法の工夫としてソマトスタチンアナログを腸 管から吸収させる取り組みがなされており期待 される ${ }^{19)}$.

\section{1）プロラクチン産生腫瘍の治療薬}

高プロラクチン血症の患者で薬剤, 妊娠, 原 発性甲状腺機能低下症などの他の原因がなく, 下垂体腺腫がその原因と判断される場合は内科 治療が優先される．他の下垂体腺腫では外科治 療が第一選択となるが, プロラクチン産生腺腫 においては内科治療が第一選択になる.これは, $\mathrm{D}_{2}$ アゴニストによりプロラクチン值の正常化の みならず腫瘍の縮小が期待でき，希には腫瘍の 消失までが観察されることによる.

血清プロラクチン值と腫瘍の大きさには相関 がある. Maroadenomaであるにもかかわらず 100 $\mathrm{ng} / \mathrm{ml}$ 程度のプロラクチン值である場合は, stalk compressionによる高プロラクチン血症や, 下垂 体のsilent subtype 3 adenomaなどの他の原因を 考慮する必要がある。その場合, $\mathrm{D}_{2}$ アゴニスト によってプロラクチン值は正常化しても腫瘍縮 小は見られず, 腫瘍の自然な増大で視力視野障 害などの合併症を起こす恐れもある．高プロラ クチン血症により女性では無月経, 乳汁分泌, 性ステロイドの低下による骨そしょう症, 性欲 の低下がみられ，男性では，性欲の低下，無精 子症などが生じる. 腫瘍のmass effectにより視力 視野障害, 動眼神経麻㿁などがおこる。このた め治療には, プロラクチン值の正常化と腫瘍縮 小が求められる.
2） $D_{2}$ アゴニスト

$\mathrm{D}_{2}$ アゴニストには, ブロモクリプチンやカベ ルゴリンなどがあるが, プロラクチン低下作用, 腫瘍縮小作用に優れるカベルゴリンが推奨され る.メ夕解析では腫瘍縮小 $(62 \%: 20 \sim 100 \%)$, 視野欠損の改善 $(67 \%: 33 \sim 100 \%)$ ，無月経の 改善 (78\% : 40 100\%), 妊娠 (53\%：10～100\%), 性機能の改善 (67\%: 6〜 100\%), 乳汁分泌の消 失 $(86 \%: 33 \sim 100 \%)$ ，プロラクチン值の正常 化 (68\%：40～100\%)などの効果が認められる. 455 例の後ろ向き研究で, 高プロラクチン血症と 微小プロラクチノーマ患者の 92\%, マクロプロ ラクチノーマ (181 例) の $77 \%$ でプロラクチン 值を正常化している. 男性でも, 性機能の回復, 精子数や機能の改善が見られる. 異なる薬剤間 の直接比較をした報告はないが，ブロモクリプ チンでは 3 分の 2 の患者で腫瘍サイズはほぼ半 減し, カベルゴリンではさらに縮小率が高いこ とが報告されている．週一回の投与で有効であ り，承認用量の上限は週 $1 \mathrm{mg}$ である.

\section{3）作用機構}

D2 アゴニストによるプロラクチン分泌抑制は 先端巨大症における $\mathrm{D}_{2}$ アゴニストやソマトスタ チンアナログの作用機構と同様で, $\mathrm{Gi}_{3}$ 蛋白を介 した内向き整流性カリウムチャネルの活性化に より膜を過分極し, 活動電位の発生を抑え, 活 動電位発生の際に細胞内に流入するカルシウム 量が減少し, 膜直下のカルシウム濃度の低下に より GH分泌顆粒の顆粒分泌を抑制することによ る.腫瘍縮小作用については, アポトーシスの 促進, 増殖能の抑制などの機構が報告されてい $ろ^{20,21)}$.

\section{5. 下垂体癌の治療薬}

下垂体腺腫に転移や脳内播種を伴う悪性転化 症例（下垂体癌）は少ないものの, 予後不良で あり, 治療も難渋する. 外科的治療, 放射線治 
療に加え化学療法薬による治療も行われている. 脳腫瘍のgliomaの治療に保険適応のあるテモゾロ ミドが下垂体癌に有用であることが報告されて いる．経口のアルキル化剤でダカルバジンのプ ロドラッグであり, cell cycle specificでないこと から神経内分泌腫瘍などの増殖能の低い腫瘍で も有効である。下垂体癌や増殖能の高い下垂体 腺腫に用いられている。 テモゾロミドの有効性 はDNA修復酵素である, MGMT (O6-methylguanine-DNAmethyltranferase）の発現によっ て左右されることが報告されていたが22)，この酵 素の発現のみで有効性が決定されるわけでもな いことが次第にわかり始めている ${ }^{23)}$. MGMT 以外に, 治療反応性を左右するものとして, DNA mismatch repair geneMSHであるMSH6 遺伝子 の発現が関与してることがあることがわかって きた。

\section{6. 成長ホルモン補充療法}

かつては, 汎下垂体機能低下症患者に対して は, 甲状腺ホルモン, 副腎皮質ホルモン, 性ホ ルモンを補充するのみで, 成長ホルモン $(\mathrm{GH})$ の 補充は行われてこなかった. GH分泌不全による 低身長患者においても，成人身長に到達したと ころでGH補充は中止されていた。しかし 1980 年代からGH補充を行われていない患者では, 体 幹の脂肪蓄積が多い, 気力が少ない, 疲れやす いなどの症状が一般人口に比べて多いことが気 づかれはじめた。

GHは, 出生直後と思春期に分泌が多いが，成 人身長に達した後も分泌は続き, 分泌量は少な くなるものの一生の間続いている. ホルモン産 生と分泌というエネルギーを必要とする機能が 成長期以降も続いていることには理由があり， 成長期以降にも成長ホルモンの生理的機能があ ると考えられる。このことが詳しく解明される ようになったのは 1980 年代以降である. GH補充
を受けていない汎下垂体機能低下症患者におい ては, 体組成の変化（体脂肪とくに体幹脂肪の 増加と徐脂肪体重 (筋肉量) の低下), 脂質プロ ファイルの変化, 骨密度の低下, QOLの悪化が 報告され成人成長ホルモン分泌不全症として認 識されるようになった. 1990 年にGH補充を受け ていない汎下垂体機能低下症の患者が一般人口 よりも生命予後が明らかに悪い（SMRで約 2 倍)ことが示され ${ }^{24)}$, 成人成長ホルモン分泌不全 症は重大な疾患であることが明らかになった。 その後, GH補充で生命予後やこれらの症状が改 善するかが研究された. QOLを含めたほとんど の症状, 症候が $\mathrm{GH}$ 補充で改善することが明らか になり，また今年になってGH補充により生命予 後も改善することが示された ${ }^{25)}$.これらの結果や, 本邦での治験の成績から, 本邦でも 2006 年から 成人成長ホルモン分泌不全症の重症例に対して $\mathrm{GH}$ 補充が保険適応となった. 本邦でのGH補充後 の臨床報告でも，体組成の改善，脂質プロファ イルの改善が示されている. QOLについても下 垂体疾患特異的な $\mathrm{QOL}$ 評価法 (ARQ試験紙) の 開発により改善が示された ${ }^{26)}$.

AGHDの患者においてNAFLD, NASHの発症 が臨床的に問題であることが明らかになりつつ ある。

成人 $\mathrm{GH}$ 分泌不全症の患者に脂肪肝が多いこと を初めて（2003 年）報告したのは長崎大学のグ ループで27), その後海外からも報告されている. 比較的, 早期に脂肪肝 (non-NAFLD) が生じ, 一部の患者では非アルコール性脂肪肝炎（nonalcoholic steatohepatitis：NASH）から肝硬変に 至る症例も存在する。この脂肪肝の発症には, GH欠乏とそれに伴う脂肪代謝の異常が関係して いると考えられるが, $\mathrm{GH}$ 補充により肝機能のみ ならず肝の線維化も改善することが報告され28), $\mathrm{GH}$ 補充療法の重要性を再確認させるものとなっ ている. 
著者のCOI (conflicts of interest) 開示：本論文発表内容に 関連して特に申告なし

\section{文献}

1) Holdaway IM, et al : A meta-analysis of the effect of lowering serum levels of GH and IGF-I on mortality in acromegaly. Eur J Endocrinol 159: 89-95, 2008.

2) 昭和 57 年 厚生労働省間脳下垂体機能障害調查研究班報 告書.

3) Holdaway IM, et al : Factors influencing mortality in acromegaly. J Clin Endocrinol Metab 89 : 667-674, 2004.

4) Giustina A, et al : Criteria for cure of acromegaly : a consensus statement. J Clin Endocrinol Metab 85 : 526-529, 2000.

5) Giustina A, et al ; Acromegaly Consensus Group : A consensus on criteria for cure of acromegaly. Clin Endocrinol Metab 95 : 3141-3148, 2010.

6) 平成 17 年度 厚生労働省間脳下垂体機能障害調査研究班 報告書

7) Ayuk J, et al : Growth hormone and pituitary radiotherapy, but not serum insulin-like growth factor-I concentrations, predict excess mortality in patients with acromegaly. J Clin Endocrinol Metab 89 : 1613-1617, 2004.

8) Yamashita $\mathrm{N}$, et al:Simultaneous measurement of changes in the membrane potential and intracellular $\mathrm{Ca}^{2+}$ concentration caused by somatostatin in human GH-producing pituitary tumor cells. Endocrinol Jpn 39 : 491, 1992.

9) Takano K, et al : Gi3 mediates somatostatin-induced activation of an inward rectifyer $\mathrm{K}^{+}$current in human GHsecreting cells. Endocrinology 138 : 2405-2409, 1997.

10) Maiza JC, et al : Long-term (up to 18 years) effects on GH/IGF-1 hypersecretion and tumour size of primary somatostatin analogue (SSTa) therapy in patients with GH-secreting pituitary adenoma responsive to SSTa. Clin Endocrinol (Oxf) 67 (2) : 282-289, 2007.

11) Cozzi R, et al : Primary treatment of acromegaly with octreotide LAR : a long-term (up to nine years) prospective study of its efficacy in the control of disease activity and tumor shrinkage. J Clin Endocrinol Metab 91 : 1397-1403, 2006.

12) Bevan JS, et al: Primary medical therapy for acromegaly: an open, prospective, multicenter study of the effects of subcutaneous and intramuscular slow-release octreotide on growth hormone, insulin-like growth factor-I, and tumor size. J Clin Endocrinol Metab 87 : 4554-4563, 2002.

13) Jallad RS, et al : Does partial surgical tumour removal influence the response to octreotide-LAR in acromegalic patients previously resistant to the somatostatin analogue? Clin Endocrinol (Oxf) $67: 310-315,2007$.
14) Takano $\mathrm{K}$, et al : Activation of $\mathrm{G}$ protein-coupled $\mathrm{K}^{+}$ channels by dopamine in human GH-producing cells. Am J Physiol E318-E325, 1994.

15) Sandret $\mathrm{L}$, et al : Place of cabergoline in acromegaly : a meta-analysis. J Clin Endocrinol Metab 96 : 1327-1335, 2011.

16) van der Lely AJ, et al:Long-term treatment of acromegaly with pegvisomant, a growth hormone receptor antagonist. Lancet 358 (9295) : 1754-1759, 2001.

17) Neggers SJ, van der Lely AJ : Somatostatin analog and pegvisomant combination therapy for acromegaly. Nat Rev Endocrinol 5 : 546-552, 2009.

18) Petersenn $\mathrm{S}$, et al; Pasireotide Acromegaly Study Group : Pasireotide(SOM230) demonstrates efficacy and safety in patients with acromegaly : a randomized, multicenter, phase II trial. J Clin Endocrinol Metab 95 : 27812789, 2010.

19) Maggio ET, Grasso P : Oral delivery of octreotide acetate in Intravail ${ }^{\mathbb{R}}$ improves uptake, half-life, and bioavailability over subcutaneous administration in male Swiss Webster mice. Regul Pept 2011 Epub ahead of print.

20) Eguchi K, et al: Effect of cabergoline, a dopamine agonist, on estrogen-induced rat pituitary tumors:in vitro culture studies. Endocr J 42: 413-420, 1995.

21) Eguchi $K$, et al: In vivo effect of cabergoline, a dopamine agonist, on estrogen-induced rat pituitary tumors. Endocr J 42 : 153-161, 1995.

22) Raverot G, et al : Temozolomide Treatment in Aggressive Pituitary Tumors and Pituitary Carcinomas: A French Multicenter Experience. J Clin Endocrinol Metab 95 : 4592-4599, 2010.

23) Murakami M, et al : A mechanism of acquiring temozolomide resistance during transformation of atypical prolactinoma into prolactin-producing pituitary carcinoma : case report. Neurosurgery 68: E1761-E1767, 2011.

24) Rosén $\mathrm{T}$, et al: Premature mortality due to cardiovascular disease in hypopituitarism. Lancet 336 (8710) : 285$288,1990$.

25) Christa C, et al: Does growth hormone replacement therapy reduce mortality in adults with growth hormone deficiency? Data from the Dutch National Registry of Growth Hormone Treatment in adults. J Clin Endocrin Metab 96 : 3151-3159, 2011.

26）成長科学協会 2008 年報告書.

27) Ichikawa $\mathrm{T}$, et al : Non-alcoholic steatohepatitis and hepatic steatosis in patients with adult onset growth hormone deficiency. Gut 52 : 912-916, 2003.

28) Takahashi Y, et al: Growth hormone reverses nonalcoholic steatohepatitis in a patient with adult growth hormone deficiency. Gastroenterology 132 : 938-943, 2007. 